\title{
Thermal-Biological Aspects of Seed Germination of Colubrina glandulosa Perkins Under Different Temperatures
}

\author{
João Luciano de A. Melo Jr. ${ }^{1}$, Luan Danilo F. de A. Melo ${ }^{1}$, Vilma M. Ferreira ${ }^{1}$, João C. de Araújo Neto ${ }^{1}$, \\ Clíssia B. da Silva ${ }^{1} \&$ Maria Inajal R. da S. das Neves ${ }^{1}$ \\ ${ }^{1}$ Center of Agricultural Sciences, Federal University of Alagoas, Alagoas, Brazil \\ Correspondence: João Luciano de A. Melo Jr., Center of Agricultural Sciences, Federal University of Alagoas, \\ 104, Km 85, s/n, 57.100-000, Rio Largo, Alagoas, Brazil. E-mail: luciiano.andrade@yahoo.com.br
}

Received: March 20, 2018

doi:10.5539/jas.v10n6p390

\begin{abstract}
The aim of this study was to determine the cardinal temperatures for germinating colubrina seeds, verify isothermal velocity variation based on the transition state model and calculate the $\Delta \mathrm{H}^{\neq}$variation as a function of temperature. Seeds were incubated at constant temperatures of $5,10,15,20,25,30,35$ and $40{ }^{\circ} \mathrm{C}$ and alternating temperature from $20-30^{\circ} \mathrm{C}$ in an 8-hour photoperiod. The variables analyzed were: G, PC, IVG, TMG, VMG, Fi, $\mathrm{U}, \mathrm{Z}, \mathrm{CR}, \mathrm{CPA}, \mathrm{MSR}$ and MSP. Arrhenius equation was linearized by logarithmic transformation, producing the graph of $-\mathrm{R} \ln V \times 1 / \mathrm{T}$ from the experimental values of velocity. A net enthalpy change $\left(\Delta \mathrm{H}^{\neq}\right)$in relation to temperature was represented by the expression: $\Delta H^{f}=\left[R T(\theta-T) \cdot\left(T_{m}+T_{M}\right)\right] /\left[\left(T-T_{m}\right) \cdot\left(T_{M}-T\right)\right]$. The logarithm regression of the reaction rate on the reciprocal of the temperature fit best to the quadratic model. The distribution of $\Delta \mathrm{H}^{\neq}$with asymptotes close to $\mathrm{T}_{\mathrm{m}}$ and $\mathrm{T}_{\mathrm{M}}$ indicated that the processes that occurred in the supra-optimal temperature range were of a different nature from those that occurred in the infra-optimal temperature range. The data showed $\left|\Delta \mathrm{H}^{\ddagger}\right|<12 \mathrm{Kcal} / \mathrm{mol}$ in the optimal range and $\left|\Delta \mathrm{H}^{\ddagger}\right|>30 \mathrm{Kcal} / \mathrm{mol}$ for temperatures of 10,15 and $35{ }^{\circ} \mathrm{C}$. The minimum and maximum temperature limits were 10 and $35{ }^{\circ} \mathrm{C}$, respectively. Germination speed was related to temperature in a curvilinear manner. The germination process was endergonic and only occurred when energy was $\geq-38.35 \mathrm{Kcal} / \mathrm{mol}$ and $\leq 32.42 \mathrm{Kcal} / \mathrm{mol}$.
\end{abstract}

Keywords: arrhenius equation, colubrina, net enthalpy change, transition state model

\section{Introduction}

Colubrina glandulosa Perkins, popularly known as colubrina, is a rare heliophyte and selective hygrophyte tree species (family Rhamnaceae), which is native and distributed in South America, ranging from the coastal Brazil to Bolivia, Paraguay, and Peru. Its wood is suitable for civil and naval construction and external and hydraulic projects. The wood produces high quality charcoal and firewood. It also presents ornamental value, and is indicated for urban afforestation. Its flowers are honey-bearing and suppliers of nectar and pollen. This species has been recommended to help recover degraded ecosystems due to its rapid growth (Lorenzi, 2016). It has phytotherapeutic value, as the leaves and bark can be used as a fever reducer or for vitamin C deficiency. Carvalho (2005) classified this species in the initial secondary ecological group.

In view of the ancient logging and relictual situation of the colubrina populations, the seeds should receive special attention for conservation, and should be present in heterogeneous forests that are permanently preserved. A lack of specific information is available on the ecophysiology of seed germination of this species in the Rules for Seed Analysis (Brasil, 2009) and Instructions for Analysis of Seeds of Forest Species (Brasil, 2013). This species does not have established criteria for standardizing seedling production methods.

Temperature is one of the main environmental factors that govern seed germination, as it strongly influences both the rate of water imbibition by the seed and the biochemical reactions that determine the entire process (Oliveira, França, Torres, Nogueira, \& Freitas, 2016). Consequently, temperature variations affect the speed, percentage, and uniformity of germination (Carvalho \& Nakagawa, 2012). Each species has a temperature range where germination will occur and is considered optimal, where the efficiency of the process is total, and extreme limits of maximum and minimum tolerated by the seeds, above or below which, respectively, germinability cannot be measured (Bastos, Ferraz, Lima Junior, \& Pritchard, 2017). Therefore, species with different 
geographic and ecological distributions should produce seeds with variations regarding the thermal requirement for germination.

Based on these findings and considering that the study species is in the list of endangered Brazilian flora species, the present study was carried out with the objective of evaluating the ecological and applied aspects of temperature during germination of colubrina seeds, to verify the variations in germination speed along the entire thermal interval based on the transition state model, and estimate net variation for the activation of enthalpy for germination as a function of temperature.

\section{Material and Methods}

The experiment was conducted at the Laboratory of Seed Analysis, Agricultural Sciences Center, Federal University of Alagoas, Rio Largo, AL, Brazil.

\subsection{Plant Material}

The fruits were harvested from October to December 2015 to obtain the seeds from 10 trees belonging to forest fragments located in the municipality of Bom Conselho, PE, located at $09^{\circ} 10^{\prime} 11^{\prime \prime} \mathrm{S}, 36^{\circ} 40^{\prime} 47^{\prime \prime} \mathrm{W}$ and at 654 meters of altitude. According to the climatic classification of Köppen, the climate is BSh, semi-arid hot. The geographical location of this region is shown in Figure 1.

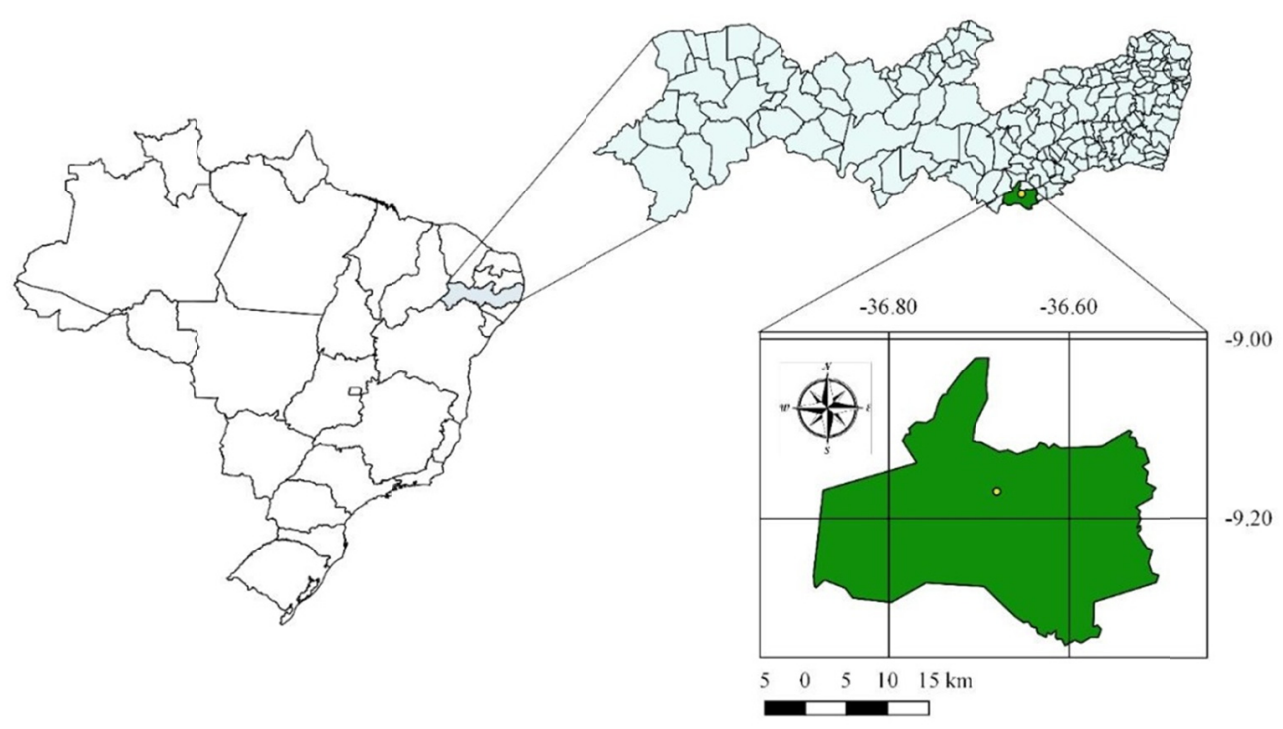

Figure 1. Geographic location of the seed collection region

The fruits were harvested with aerial scissors and an extensor cable at the end of the maturation period and held in the shade (shelter protected from sun and rain) for a few days to complete the drying process and facilitate dehiscence of fruits.

\subsection{Isothermal Seed Germination}

The isothermal incubation was carried out in a biological oxygen demand type germination chamber, at constant temperatures of $5,10,15,20,25,30,35$, and $40^{\circ} \mathrm{C}$ and alternating $20-30{ }^{\circ} \mathrm{C}$, with a photoperiod of 8 hours light, simulated by four $20 \mathrm{~W}$ fluorescent daylight bulbs. The accuracy of the temperature control was within the range of $\pm 0.5^{\circ} \mathrm{C}$. Before the germination test, the seeds were cleaned in $70 \%$ alcohol for $1 \mathrm{~min}$, followed by washes in running water (Rios, Araújo Neto, Ferreira, \& Neves, 2016). Afterwards, the mechanical scarification treatment with scissors in the region opposite the hilum was used, and the seeds were placed to germinate on two sheets of paper towels moistened with distilled water volume equivalent to 2.5 times the dry paper weight (Brasil, 2009) and contained in clear plastic boxes $(11.0 \times 11.0 \times 3.5 \mathrm{~cm})$.

The seeds were considered germinated when they produced seedlings classified as normal (Brasil, 2009). The germinated seeds were counted daily for 19 days during the test. Water was added, when necessary, to ensure that the substrate remained sufficiently moist throughout the experiment. At constant temperatures of 5, 10, and 
$15^{\circ} \mathrm{C}$, the test was extended for another 7 days by transferring the seeds to the ideal temperature. The variables analyzed were:

(a) Germinability: $g i=(\Sigma k i=1 \mathrm{ni} / \mathrm{N}) \times 100($ Carvalho, Santana, \& Ranal, 2005); where, ni the number of seeds germinated in time $i$ and $\mathrm{N}$ the total number of seeds placed to germinate.

(b) First germination count: It was performed together with the germination test by computing the percentage of normal seedlings obtained on the third day after the test started.

(c) Speed index of germination: IVG $=\mathrm{G}_{1} / \mathrm{N}_{1}+\mathrm{G}_{2} / \mathrm{N}_{2}+\ldots+\mathrm{G}_{\mathrm{n}} / \mathrm{N}_{\mathrm{n}}$ (Maguire, 1962); where, $\mathrm{G}_{1}, \mathrm{G}_{2}$, and $\mathrm{G}_{\mathrm{n}}$ are the number of seeds germinated in the first, second, and last count; and $\mathrm{N}_{1}, \mathrm{~N}_{2}$, and $\mathrm{N}_{\mathrm{n}}$ are the number of sowed days at the first, second, and last count.

(d) Mean germination time: $t=\Sigma k i=1($ niti) $/ \Sigma k i=1 \mathrm{ni}$; where, ti is the time from the start of the experiment to the $i$ nth observation (days or hours); ni is the number of seeds germinated at time $i$ (corresponding number or $i$ nth observation); and $k$ is the last day of germination.

(e) Average speed of germination: $v=1 / t$ (Ranal \& Santana, 2006); where, $t$ is average germination time.

(f) Relative germination frequency: $\mathrm{Fi}=\mathrm{ni} / \Sigma k i=1 \mathrm{ni}$; where, ni is the number of seeds germinated per day and $\Sigma$ ni is the total number of germinated seeds.

(g) Uncertainty index: $\mathrm{U}=-\Sigma k i=1 \mathrm{Fi} \log _{2} \mathrm{Fi}=\mathrm{Fi}=\mathrm{ni} / \Sigma k i=1 \mathrm{ni}$; where, $\mathrm{Fi}$ is the relative frequency of germination; ni is the number of seeds germinated at time $i$ (corresponding number or $i$ nth observation); and $k$ is the last day of germination.

(h) Synchronicity index: $\mathrm{Z}=\Sigma \mathrm{C}_{\mathrm{n} 1,2} / \mathrm{N}=\mathrm{C}_{\mathrm{n} 1,2}=\mathrm{ni}(\mathrm{ni}-1) / 2 ; \mathrm{N}=\Sigma \mathrm{ni}(\Sigma \mathrm{ni}-1) / 2$ (Primack, 1980); where, $\mathrm{C}_{\mathrm{n} 1,2}$ is the combination of seeds germinated in the $i$ th time, and ni is the number of seeds germinated at time $i$.

(i) Length of aerial part and primary root: At the end of the germination test, the lengths of the primary root (from the base of the neck to the end of the primary root) and of the aerial part (from the collar to the apex of the seedling) of the normal seedlings in the experimental unit were measured using a graduated ruler.

(j) Aerial part dry mass and primary root: After the measurements, the roots and aerial part of the normal seedlings of the experimental unit were conditioned in Kraft paper bags and placed in a forced air circulating oven, regulated at $80^{\circ} \mathrm{C}$, until the samples reached constant weight $(24 \mathrm{~h})$. Then, dry mass was determined on a precision analytical balance $(0.0001 \mathrm{~g})$.

Based on the activated complex model, the graph with the coordinates $\mathrm{y}=-\mathrm{R} \ln \mathrm{V}(\mathrm{V}=$ experimental values of velocity $)=\mathrm{A}(1 / \mathrm{T}) \times 10^{5}$, with $\mathrm{R}=1,987 \mathrm{Kcal} \mathrm{mol}^{-1}$ and $\mathrm{T}$ in Kelvin, was constructed to explain variations in germination velocity over the entire thermal range.

From the Arrhenius equation $\partial(-\mathrm{R} \ln \mathrm{V}) / \partial(1 / \mathrm{T})=\Delta \mathrm{H}^{\neq}+\mathrm{RT}$, the net energy change (enthalpy) of germination activation was calculated for both the infra (V1) and the supra-optimal (V2), using the minimum $\left(\mathrm{T}_{\mathrm{m}}\right)$ and maximum $\left(\mathrm{T}_{\mathrm{M}}\right)$ germination temperatures as parameters (Labouriau \& Osborn, 1984). Thus, in the range V1, $\Delta \mathrm{H}_{1}^{\neq}=\mathrm{RT}_{\mathrm{m}} \cdot\left[\mathrm{T} /\left(\mathrm{T}-\mathrm{T}_{\mathrm{m}}\right)\right]$, and in the range $\mathrm{V} 2, \Delta \mathrm{H}_{2}^{\neq}=-\mathrm{RT}_{\mathrm{M}} \cdot\left[\mathrm{T} /\left(\mathrm{T}_{\mathrm{M}}-\mathrm{T}\right)\right]$, the net change in enthalpy $\left(\Delta \mathrm{H}^{\ddagger}\right)$ as a function of temperature was represented by the expression: $\Delta \mathrm{H}^{\neq}=\left[\mathrm{RT} \cdot(\theta-\mathrm{T}) \cdot\left(\mathrm{T}_{\mathrm{m}}+\mathrm{T}_{\mathrm{M}}\right)\right] /\left[\left(\mathrm{T}-\mathrm{T}_{\mathrm{m}}\right) \cdot\left(\mathrm{T}_{\mathrm{M}}-\mathrm{T}\right)\right]$, where, $\theta$ (harmonic mean of minimum and maximum temperatures) $=\left[\left(2 \mathrm{~T}_{\mathrm{m}} \cdot \mathrm{T}_{\mathrm{M}}\right) /\left(\mathrm{T}_{\mathrm{m}}+\mathrm{T}_{\mathrm{M}}\right)\right]$, and $\mathrm{T}$ the experimental temperature, following the physiological interpretation of the opposite signs of $\Delta \mathrm{H}^{\neq}$in the infra and supra-optimal bands of germination.

The experimental design was completely randomized, with four replicates of 25 seeds per treatment. Data were submitted to analysis of variance and the means were compared by Tukey's test at a 5\% probability. A polynomial regression analysis was performed to test the linear and quadratic models for quantitative effects, and the most significant $\mathrm{R}^{2}$ was selected. The statistical program used was Sisvar version 5.6 (Ferreira, 2011).

The stochastic model is: $\mathrm{Y}_{i j}=\mu_{i}+\varepsilon_{i j}(i=1, \ldots k$ and $j=1, \ldots r)$; where, $i$ is the index referring to the treatment and $\mathrm{j}$ is the experimental unit.

\section{Results and Discussion}

The colubrina seeds germinated in the range $10{ }^{\circ} \mathrm{C} \leq \mathrm{T} \leq 35{ }^{\circ} \mathrm{C}$, with the minimum cardinal point at $5{ }^{\circ} \mathrm{C}<\mathrm{T}<$ $10{ }^{\circ} \mathrm{C}$, and the maximum at $35^{\circ} \mathrm{C}<\mathrm{T}<40{ }^{\circ} \mathrm{C}$, i.e., no germination occurred at $5{ }^{\circ} \mathrm{C}$ or $40{ }^{\circ} \mathrm{C}$, resulting in physiological adaptation of the seeds to the environmental conditions for the species. The optimum temperature was $25{ }^{\circ} \mathrm{C}<\mathrm{T}<30{ }^{\circ} \mathrm{C}$, which allowed high germinability at a lower germination time (TMG) (Table 1). Nevertheless, the seeds present some plasticity regarding this adaptive character, as this species occurs over several Brazilian states, in regions of transition between the Cerrado or Atlantic Forest biomes for the Caatinga. 
The temperature variation $\left(20-30{ }^{\circ} \mathrm{C}\right)$ did not increase the percentage of germination $(\mathrm{G})$ compared to the constant temperature of $20{ }^{\circ} \mathrm{C}$ (Table 1). F. N. Oliveira, J. R. Oliveira, Torres, Freitas, and Nogueira (2017) reported that the efficiency of germination can be quantified using the ideal temperature and maximum and minimum temperature limits. Other trees in the Caatinga biome present similar thermal requirements: Amburana cearensis (Allemão) A. C. Sm. $\left(20^{\circ} \mathrm{C} \leq \mathrm{T} \leq 40{ }^{\circ} \mathrm{C}\right.$ ) (Almeida et al., 2017), Mimosa ophthalmocentra Mart. ex Benth. $\left(25^{\circ} \mathrm{C} \leq \mathrm{T} \leq 35^{\circ} \mathrm{C}\right)$ (Nogueira, Torres, Freitas, Castro, \& Sá, 2017), Mimosa tenuiflora Willd. $\left(20^{\circ} \mathrm{C} \leq \mathrm{T}\right.$ $\leq 40{ }^{\circ} \mathrm{C}$ ) (Benedito, Ribeiro, Torres, Guimarães, \& Oliveira, 2017), and Senegalia bahiensis (Benth.) Seigler \& Ebinger $\left(25^{\circ} \mathrm{C} \leq \mathrm{T} \leq 30^{\circ} \mathrm{C}\right)$ (Lima, Mendonça, Paixão, Freitas, \& Moreira, 2017).

Increasing the experimental temperature increased G, first count (PC) and germination speed index (IVG), within a certain limit, but temperatures $>30{ }^{\circ} \mathrm{C}$ caused a marked reduction in total germination until the maximum temperature was reached $\left(35^{\circ} \mathrm{C}\right)$ (Table 1). No seeds germinated at $35^{\circ} \mathrm{C}$, due to thermoinhibition, which can also cause thermal dormancy or loss of viability. On the other hand, a small number of seeds germinated $(12 \%)$ at $10{ }^{\circ} \mathrm{C}$ during the 19 day incubation (Table 1), contributing to the proliferation of microorganisms harmful to the establishment of the seedlings. Low temperatures may have resulted in the gradual immobilization of seed reserves, gradually decreasing the percent germination (R. B. Silva, Matos, Farias, Sena, \& D. Y. B. O. Silva, 2017).

Table 1. Germination (G), first count (PC), germination speed index (IVG) and mean germination time (TMG) of C. glandulosa seeds, submitted to different temperatures

\begin{tabular}{lllll}
\hline Temperatures $\left({ }^{\circ} \mathrm{C}\right)$ & $\mathrm{G}(\%)$ & PC $(\%)$ & IVG & TMG (days) \\
\hline 10 & $12 \mathrm{e}$ & $0 \mathrm{f}$ & $0.331 \mathrm{~g}$ & $12.0 \mathrm{f}$ \\
15 & $32 \mathrm{~d}$ & $2 \mathrm{ef}$ & $0.919 \mathrm{f}$ & $10.0 \mathrm{e}$ \\
20 & $59 \mathrm{c}$ & $6 \mathrm{~d}$ & $2.618 \mathrm{~d}$ & $6.2 \mathrm{~d}$ \\
25 & $73 \mathrm{~b}$ & $29 \mathrm{~b}$ & $4.707 \mathrm{~b}$ & $4.2 \mathrm{~b}$ \\
30 & $97 \mathrm{a}$ & $58 \mathrm{a}$ & $7.033 \mathrm{a}$ & $3.6 \mathrm{a}$ \\
35 & $28 \mathrm{~d}$ & $4 \mathrm{de}$ & $1.443 \mathrm{e}$ & $5.3 \mathrm{c}$ \\
$20-30$ & $61 \mathrm{c}$ & $11 \mathrm{c}$ & $3.469 \mathrm{c}$ & $4.7 \mathrm{~b}$ \\
\hline Value of “F” & $495.74^{* *}$ & $569.54^{* *}$ & $933.61^{* *}$ & $1160.59^{* *}$ \\
$\mathrm{CV}(\%)$ & 6.67 & 13.36 & 6.94 & 4.59 \\
\hline
\end{tabular}

Note. Means followed by the same lowercase letter in the column do not differ from each other to a $5 \%$ probability by the Tukey test.

** Significant at the $1 \%$ probability level.

The Arrhenius curve is shown in Figure 2. The typical unimodal relationship between the logarithm of the reaction velocity and the reciprocal of the temperature better fit a quadratic regression model, where the decreasing part of the curve represented the supra-optimal thermal range, and the increasing part of the curve corresponded to the infra-optimal range. Based on the activated complex model and isothermal dependence of germination, the theoretical optimum temperature for velocity was $31.4^{\circ} \mathrm{C}$.

It should be emphasized that the energy barrier of activation encompasses both thermal and organizational transitions. The model assumes that an enzyme can exist in two states, such as active and inactive. According to Machado, Bortolin, Paranhos, and Silva (2016), products are formed when the enzyme is in its active state, which, in turn, is in equilibrium with the denatured or inactive form. As temperature increases, equilibrium shifts to the inactive enzymatic state. 


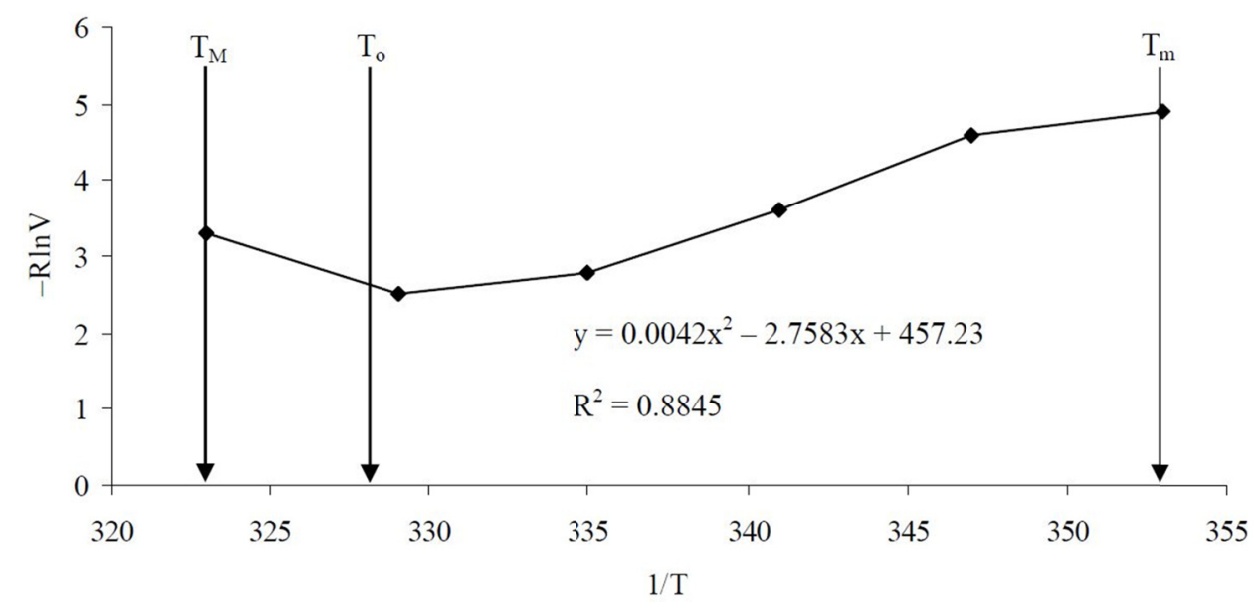

Figure 2. Arrhenius curve of the isothermal germination speed of $C$. glandulos $a$ seeds. $\mathrm{T}_{\mathrm{m}}=$ minimum temperature; $\mathrm{T}_{\mathrm{M}}=$ maximum temperature; $\mathrm{T}_{\mathrm{o}}=$ theoretical optimum temperature

The seeds showed germination capacity at well-defined temperature limits. This is an important feature; temperatures above the optimum for total germination accelerate the speed of the process, but disorganize it, so the number of seeds that can complete germination drops rapidly. However, temperatures below the optimum for germination tend to reduce the speed of the process, exposing the seedlings for a longer period of time to adverse environmental factors, which may lead to a reduction in total germination rate.

Albuquerque, Rodrigues, Minohara, Tebaldi, and Silva (1998) obtained low and slow germination with colubrina seeds held at constant temperatures of 25 and $30{ }^{\circ} \mathrm{C}$ and alternating between $20-30{ }^{\circ} \mathrm{C}$. Considering these results, immersing the seeds in sulfuric acid for 25 min may not have been sufficient to overcome dormancy.

The results of uncertainty (U) (informational entropy) (Table 2) showed that seeds subjected to temperatures in the optimum range presented frequencies with a few peaks or a supposed unimodal frequency distribution; that is, they tended to concentrate germination within the shortest time possible. Above and below this range, the $\mathrm{U}$ increased significantly and germination involved a loss of order. In turn, the presence of the main mode would no longer occur and the germination of a few seeds would appear scattered over time, with a tendency for a polymodal distribution and dispersion of the relative frequency, indicating a compensation of the unfavorable temperature conditions by greater distribution of germination in time.

Buried seeds that leave the bank and are brought to the surface at the opening of clearings are exposed to better light and temperature conditions in closed tropical forest ecosystems, which promotes germination. The ability of this species to remain dormant in the bank is an important biological strategy for the dynamics of their populations, allowing them to utilize the opening of clearings in the forest or face drastic changes in their communities. In tropical forests, seed bank formation usually occurs in species located in initial succession or clearings.

Temperatures near the optimum provided the highest synchronization indices of germination $(Z)$, confirming that this temperature range represents an environmental signal (communication of thermal energy between the external environment and the seed), which leads to a higher level of organization of the process, and reflecting higher $\mathrm{G}$ values and average germination velocity (VMG). While under lower temperatures, germination was more random and less synchronized (Tables 1 and 2). According to Medeiros, Souza, Santos, Azeredo, and Anjos (2017), this strategy provides greater efficiency to establish seedlings, as the seeds have the opportunity to produce seedlings that may find ideal conditions for development. 
Table 2. Mean germination velocity (VMG), uncertainty index (U) and synchrony index (Z) of C. glandulosa seeds, submitted to different temperatures

\begin{tabular}{llll}
\hline Temperatures $\left({ }^{\circ} \mathrm{C}\right)$ & $\mathrm{VMG}\left(\right.$ days $\left.^{-1}\right)$ & $\mathrm{U}(\mathrm{bits})$ & $\mathrm{Z}$ \\
\hline 10 & $0.08 \mathrm{~g}$ & $2.5216 \mathrm{f}$ & $0.0476 \mathrm{f}$ \\
15 & $0.10 \mathrm{f}$ & $2.4089 \mathrm{f}$ & $0.1500 \mathrm{e}$ \\
20 & $0.16 \mathrm{e}$ & $2.2258 \mathrm{e}$ & $0.1728 \mathrm{de}$ \\
25 & $0.24 \mathrm{~b}$ & $1.4688 \mathrm{~b}$ & $0.3333 \mathrm{~b}$ \\
30 & $0.28 \mathrm{a}$ & $0.9183 \mathrm{a}$ & $0.4090 \mathrm{a}$ \\
35 & $0.18 \mathrm{~d}$ & $2.0844 \mathrm{~d}$ & $0.2282 \mathrm{~cd}$ \\
$20-30$ & $0.21 \mathrm{c}$ & $1.6436 \mathrm{c}$ & $0.2787 \mathrm{bc}$ \\
\hline Value of "F" & $3345.40^{* *}$ & $1363.86^{* *}$ & $145.83^{* *}$
\end{tabular}

Note. Means followed by the same lowercase letter in the column do not differ from each other to a $5 \%$ probability by the Tukey test.

** Significant at the $1 \%$ probability level.

With the temperature dependence of the germination speed, the distribution of the isothermal germination frequencies can vary with temperature, and the analysis of these distributions suggests hypotheses about how the thermal signal is perceived by the seed (Zpevak, Perez, \& Buckeridge, 2012).

The frequency polygons are shown in Figure 3. Depending on the temperature, the asymmetry of the distribution was due to the majority of seeds that germinated rapidly or to the minority of seeds that took extra time to germinate (or due to both cases). The graphs were unimodal at constant temperatures of $20,25,30$ and $35^{\circ} \mathrm{C}$, and alternating between $20-30{ }^{\circ} \mathrm{C}$, but polymodal at constant temperatures of 10 and $15{ }^{\circ} \mathrm{C}$. A deviation in the germination time was observed with respect to the modal time; to the right $\left(t>t \mathrm{~m}_{0}\right)$, from 25 to $35^{\circ} \mathrm{C}$ and 20-30 ${ }^{\circ} \mathrm{C}$, confirming and accelerated germination process, and to the left $\left(t<t \mathrm{~m}_{0}\right)$, from 10 to $20^{\circ} \mathrm{C}$, reflecting a delay in this process. The ecological implication is that tropical and subtropical areas, especially in summer, can be an advantage for this species to establish. Sanhueza et al. (2017) reported that warmer environmental temperatures, such as those anticipated due to global warming, will increase reproduction by germination.
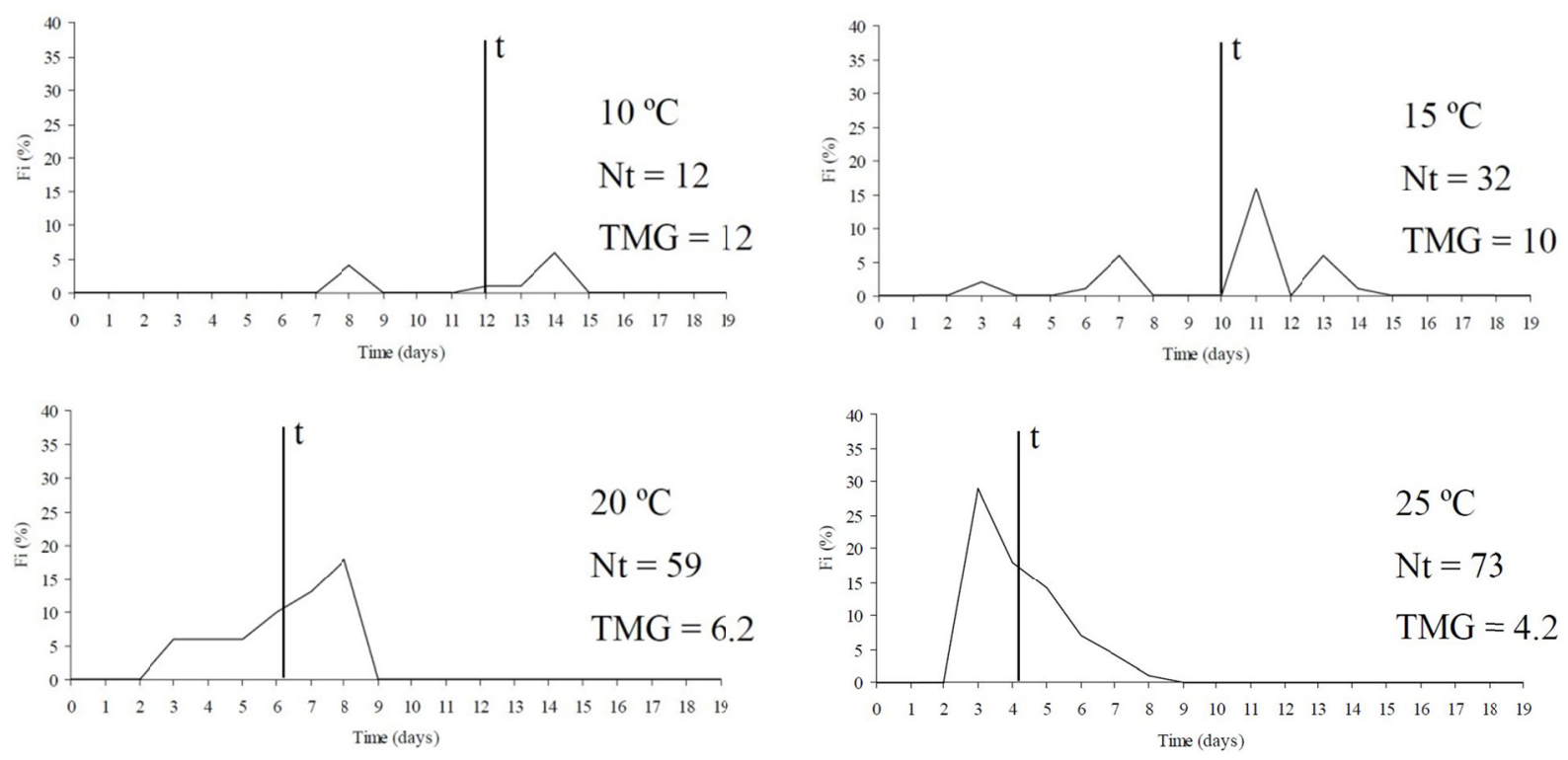

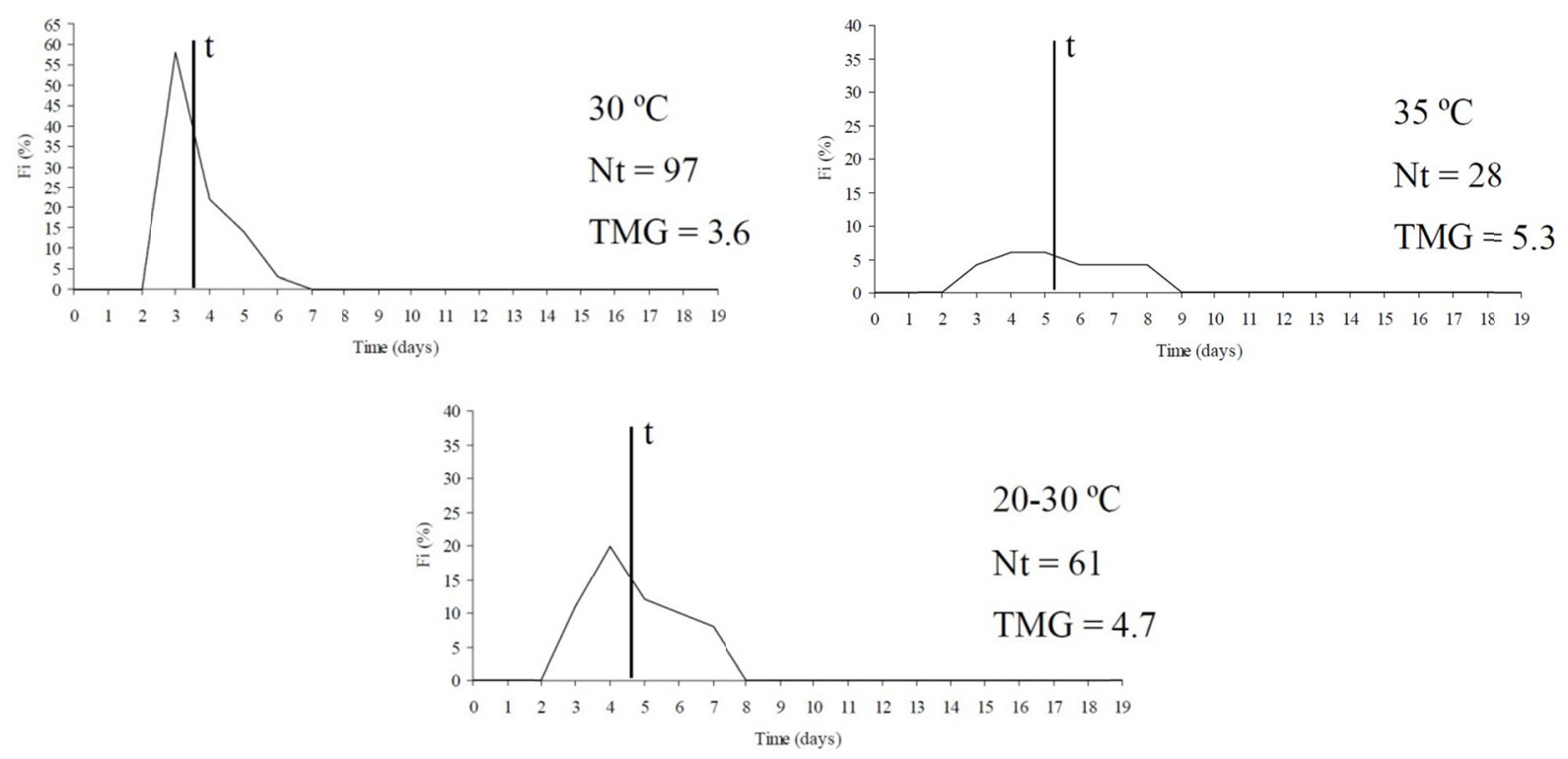

Figure 3. Relative frequencies of germination as a function of the isothermal incubation time of C. glandulosa seeds. $\mathrm{Nt}=$ total number of germinated seeds; $t=$ time of germination; $\mathrm{TMG}=$ average germination time

The minimum and maximum temperatures were 10 and $35{ }^{\circ} \mathrm{C}$, respectively, and the harmonic mean between them was $15.6^{\circ} \mathrm{C}$. Applying the laws of thermodynamics, the graph of the temperature-dependent variation in $\Delta \mathrm{H}^{\neq}$, whose curve has two asymptotes close to $\mathrm{T}_{\mathrm{m}}$ and $\mathrm{T}_{\mathrm{M}}$ (Figure 4), showed that activation energy (enthalpy) of germination was negative as temperature tended toward $\mathrm{T}_{\mathrm{M}}$, as the processes are occurring in the supra-optimal range, which was different from those occurring in the infra-optimal region. We verified $\left|\Delta \mathrm{H}^{\ddagger}\right|<12 \mathrm{Kcal} \mathrm{mol}^{-1}$ in the optimum temperature range, and $\left|\Delta \mathrm{H}^{\ddagger}\right|>30 \mathrm{Kcal} \mathrm{mol}^{-1}$ for 15 and $35^{\circ} \mathrm{C}$, where thermodesaturation processes should affect the perception and transduction capacity of the thermal signal in the seed. Activation of growth will be much more efficient the less energy consumed per unit of time.

The mean $\Delta \mathrm{H}^{\ddagger}$ value, calculated for each experimental temperature range, was positive up to $30{ }^{\circ} \mathrm{C}\left(\Delta \mathrm{H}^{\ddagger}>0\right)$, with a signal inversion at $35^{\circ} \mathrm{C}\left(\Delta \mathrm{H}^{\ddagger}<0\right)$ (Table 3$)$, indicating that temperature affected the reaction rates and changed the physical state of the cellular components. The concept of energy barrier no longer makes sense at supra-optimal temperatures. The limitation of germination speed by $T_{m}$ and $T_{M}$ would be due to an energy demand above the capacity of energetic supply by the exergonic metabolic reactions.

The germination process in the optimum temperature range can be limited by diffusion phenomena during imbibition, the percentage of germination can be affected by thermal variations, with an exponential increase in tissue turgor. Mechanical scarification in the region opposite the hilum removes at least part of the physical barrier imposed by the integument. Notably, purely passive processes, such as imbibition, are less sensitive to temperature variations than metabolic processes. 


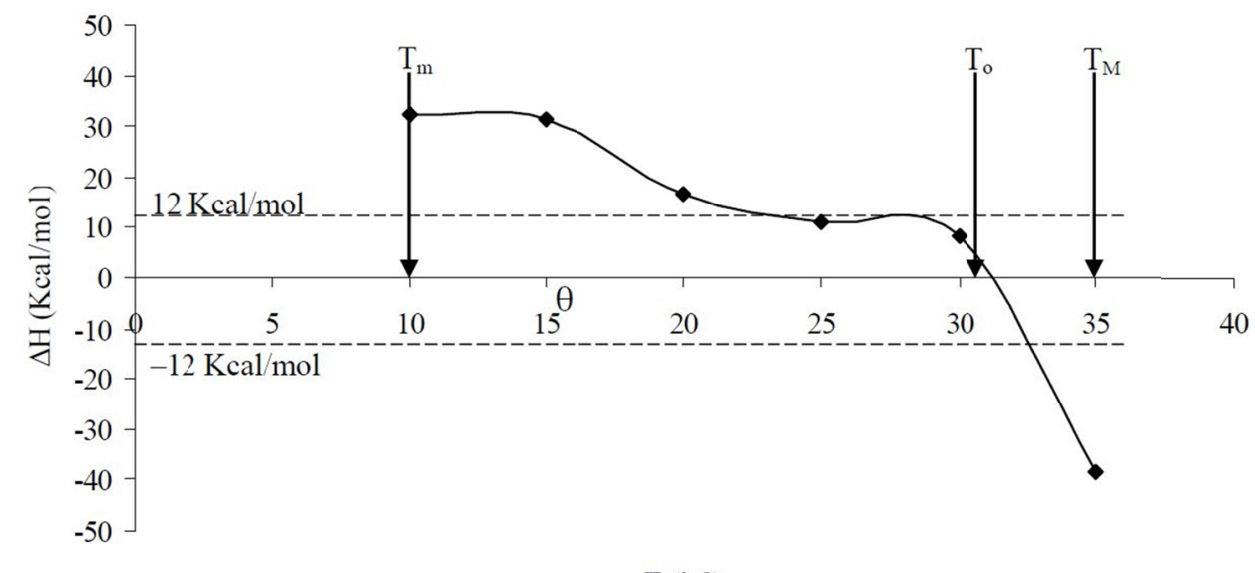

$\mathrm{T}\left({ }^{\circ} \mathrm{C}\right)$

Figure 4. Net variation of the activation enthalpy of C. glandulosa seed germination. $\mathrm{T}_{\mathrm{m}}=$ minimum temperature; $\mathrm{T}_{\mathrm{M}}=$ maximum temperature; $\mathrm{T}_{\mathrm{o}}=$ theoretical optimum temperature

Table 3. Temperature dependence of the net change in activation enthalpy $\left(\Delta \mathrm{H}^{\ddagger}\right)$ in C. glandulosa seeds.

\begin{tabular}{llll}
\hline & Temperatures & $\Delta \mathrm{T}$ & $\Delta \mathrm{H}^{\ddagger}(\mathrm{Kcal} / \mathrm{mol})$ \\
\hline${ }^{\circ} \mathrm{C}$ & $\mathrm{K}$ & $0-5$ & \\
\hline 5 & 278.15 & $5-10$ & 32.42 \\
10 & 283.15 & $10-15$ & 31.30 \\
15 & 288.15 & $15-20$ & 16.49 \\
20 & 293.15 & $20-25$ & 11.18 \\
25 & 298.15 & $25-30$ & 8.53 \\
30 & 303.15 & $30-35$ & -38.35 \\
35 & 308.15 & $35-40$ & \\
40 & 313.15 & & \\
\hline
\end{tabular}

Thus, at 15 and $35{ }^{\circ} \mathrm{C}$, high energy levels are required to trigger germination, indicating partitioning of the membrane phase/phospholipid phase changes, which are considered to be an important mechanism for limiting growth velocity, and thermo-transconformation protein, which can slow down the metabolic rate to the point where the pathways essential for germination stop (Ataíde, Borges, Picoli, Leite Filho, \& Flores, 2017). Silva, Alves, Bruno, Santos-Moura, and Santos Neto (2016) reported that many enzymatic proteins may be overly folded at low temperatures, so their active centers are not reached by the respective substrates, which makes the reaction unfeasible. On the other hand, the limitation may occur under high temperatures due to adverse transconformations, also leading to loss of catalytic activity (Melo, Cavalcante, Alves, Martins, \& Araújo, 2017).

Another process that can be affected by a decrease in temperature is the organization of tubulin in the microtubules, which are involved in synergistic partial processes acting in the infra-optimal range of germination (Bona, Karsburg, \& Gallo, 2016).

Germination velocity $(v)$ increases with temperature at infra-optimal temperatures, and the predominant reaction is endothermic (energy consuming), meaning that the overall velocity of the process is limited by partial processes whose effects increase with temperature, and that are synergistic; that is, aimed at growth of the embryo. $v$ decreases with temperature in the supra-optimal range, and the reaction is exothermic (releases heat), indicating that the velocity is also limited by processes favored by a rise in temperature, but whose effects are antagonistic; that is, the energy is diverted to other processes, not linked to the embryonic growth.

Competitive thermodenaturation should occur beyond the optimum temperature, which is indicated by the appearance of heat shock proteins, to meet the extra demands imposed on cells under stress (Taiz, Zeiger, Møller, \& Murphy, 2017).

Minimum temperatures, due to the effects on imbibition speed and mobilization of reserves, caused a decrease in root length (CR), length of the aerial part (CPA), root dry mass (MSR) and dry mass of the aerial part (MSP) 
(Table 4), which may extend the problem to the rest of the plant cycle, with effects on speed of development and production by area (Missio et al., 2017). According to Marcos-Filho (2015), injuries due to cooling are probably related to damage to the membrane system, because embryonic axes subjected to these conditions lose organic substances. Temperature has its main effect on the physical state of the cell membrane, particularly on lipid fluidity (Lopes \& Franke, 2011).

Some of the reactions that would generally culminate in the protrusion of the primary root proceeded normally at the maximum temperature, but subsequent normal seedling development did not occur (Table 4), possibly as a consequence of a lower rate of protein synthesis or other processes particularly sensitive to the temperature increase. This observation may be related to the loss of conformational structure of the enzymes at a given temperature, which also leads to loss of function or inactivation (Ataíde, Borges, \& Leite Filho, 2016).

Temperature variations within the optimum range were the most adequate for seed germination and other aspects of initial development of the plant (Tables 1,2, and 4), as there is a relationship between these temperatures and the biome where the seeds were produced.

Table 4. Root length (CR), length of the aireal part (CPA), root dry mass (MSR) and dry mass of the aireal part (MSP) of C. glandulosa seedlings, submitted to different temperatures

\begin{tabular}{lllll}
\hline Temperatures $\left({ }^{\circ} \mathrm{C}\right)$ & $\mathrm{CR}(\mathrm{mm})$ & $\mathrm{CPA}(\mathrm{mm})$ & MSR $(\mathrm{mg})$ & MSP $(\mathrm{mg})$ \\
\hline 10 & $3 \mathrm{f}$ & $36 \mathrm{f}$ & $2 \mathrm{f}$ & $26 \mathrm{e}$ \\
15 & $9 \mathrm{e}$ & $56 \mathrm{e}$ & $4 \mathrm{e}$ & $28 \mathrm{e}$ \\
20 & $19 \mathrm{~d}$ & $59 \mathrm{e}$ & $9 \mathrm{~d}$ & $38 \mathrm{~d}$ \\
25 & $28 \mathrm{~b}$ & $97 \mathrm{~b}$ & $19 \mathrm{~b}$ & $85 \mathrm{~b}$ \\
30 & $34 \mathrm{a}$ & $109 \mathrm{a}$ & $23 \mathrm{a}$ & $93 \mathrm{a}$ \\
35 & $7 \mathrm{e}$ & $76 \mathrm{~d}$ & $3 \mathrm{ef}$ & $27 \mathrm{e}$ \\
$20-30$ & $24 \mathrm{c}$ & $86 \mathrm{c}$ & $15 \mathrm{c}$ & $76 \mathrm{c}$ \\
\hdashline Value of “F” & $236.00^{* *}$ & $1462.59^{* *}$ & $429.52^{* *}$ & $920.69^{* *}$ \\
CV (\%) & 12.09 & 3.58 & 9.80 & 5.53 \\
\hline
\end{tabular}

Note. Means followed by the same lowercase letter in the column do not differ from each other to a $5 \%$ probability by the Tukey test.

** Significant at the $1 \%$ probability level.

\section{Conclusions}

Colubrina seeds presented a wide range of tolerance to temperatures, with minimum and maximum limits of 10 and $35^{\circ} \mathrm{C}$, respectively.

The optimal temperature for colubrina seed germination was $30^{\circ} \mathrm{C}$.

Germination speed was in a curvilinear relationship with temperature.

The germination process was predominantly endergonic and occurred only when an energy $\geq-38.35 \mathrm{Kcal} \mathrm{mol}^{-1}$ and $\leq 32.42 \mathrm{Kcal} \mathrm{mol}^{-1}$ was reached.

\section{Acknowledgements}

Corresponding author thanks Coordination for the Improvement of Higher Education Personnel by the granting the scholarship.

\section{References}

Albuquerque, M. C. F., Rodrigues, T. J. D., Minohara, L., Tebaldi, N. D., \& Silva, L. M. M. (1998). Influência da temperatura e do substrato na germinação de sementes de saguaraji (Colubrina glandulosa Perk. Rhamnaceae). Revista Brasileira de Sementes, 20(2), 108-111. https://doi.org/10.17801/0101-3122/rbs.v20 n2p108-111

Almeida, J. P. N., Lessa, B. F. T., Pinheiro, C. L., Gomes, F. M., Medeiros Filho, S., \& Silva, C. C. (2017). Germination and development of Amburana cearensis seedlings as influenced by seed weight, light and temperature. Acta Scientiarum. Agronomy, 39(4), 525-533. https://doi.org/10.4025/actasciagron.v39i4. 32786 
Ataíde, G. M., Borges, E. E. L., \& Leite Filho, A. T. (2016). Alterações fisiológicas e biométricas em sementes de Melanoxylon brauna Schott durante a germinação em diferentes temperaturas. Revista Árvore, 40(1), 61-70. https://doi.org/10.1590/0100-67622016000100007

Ataíde, G. M., Borges, E. E. L., Picoli, E. A. T., Leite Filho, A. T., \& Flores, A. V. (2017). Alterações nas reservas de sementes de Melanoxylon brauna Schott. (Fabaceae Caesalpinioideae) durante a germinação em diferentes temperaturas. Revista Brasileira de Ciências Agrárias (Agrária), 12(3), 372-379. https://doi.org/ 10.5039/agraria.v12i3a5454

Bastos, L. L. S., Ferraz, I. D. K., Lima Junior, M. J. V., \& Pritchard, H. W. (2017). Variation in limits to germination temperature and rates across the seed-seedling transition in the palm Oenocarpus bataua from the Brazilian Amazon. Seed Science and Technology, 45(1), 1-13. https://doi.org/10.15258/sst.2017.45.1.05

Benedito, C. P., Ribeiro, M. C. C., Torres, S. B., Guimarães, I. P., \& Oliveira, K. J. B. (2017). Dormancy overcoming, temperatures and substrates on germination of Mimosa tenuiflora Willd seeds. Semina: Ciências Agrárias, 38(1), 125-134. https://doi.org/10.5433/1679-0359.2017v38n1p125

Bona, D. A. O., Karsburg, I. V., \& Gallo, R. (2016). Indução e identificação de poliploidia em Hymenaea courbaril L. var. Stilbocarpa (Hayne) Lee et Lang. Ciência Florestal, 26(4), 1331-1337. https://doi.org/ $10.5902 / 1980509825151$.

Brasil. (2009). Ministério da Agricultura, Pecuária e Abastecimento. Regras para análise de sementes. Ministério da Agricultura, Pecuária e Abastecimento, Secretaria de Defesa Agropecuária. Brasília, DF: MAPA/ACS.

Brasil. (2013). Ministério da Agricultura, Pecuária e Abastecimento. Instruções para análise de sementes de espécies florestais. Ministério da Agricultura, Pecuária e Abastecimento, Secretaria de Defesa Agropecuária/Coordenação Geral de Apoio Laboratorial. Brasília, DF: MAPA/SDA/CGAL.

Carvalho, M. P., Santana, D. G., \& Ranal, M. (2005). A. Emergência de plântulas de Anacardium humile A. St.-Hil. (Anacardiaceae) avaliada por meio de amostras pequenas. Revista Brasileira de Botânica, 28(3), 627-633. https://doi.org/10.1590/S0100-84042005000300018

Carvalho, N. M., \& Nakagawa, J. (2012). Sementes: ciência, tecnologia e produção (5th ed.). Jaboticabal: Funep.

Carvalho, P. E. R. (2005). Sobrasil. Circular Técnica, 106. Colombo: Embrapa Florestas.

Ferreira, D. F. (2011). Sisvar: A computer statistical analysis system. Ciência e Agrotecnologia, 35(6), 1039-1042. https://doi.org/10.1590/S1413-70542011000600001

Labouriau, L. G., \& Osborn, J. H. (1984). Temperature dependence on germination of tomato seeds. Journal of Thermal Biology, 9(4), 285-294. https://doi.org/10.1016/0306-4565(84)90010-X

Lima, T. M., Mendonça, A. V. R., Paixão, C. C., Freitas, T. A. S., \& Moreira, R. F. C. (2017). Influence of temperature and photoperiod on the germination of Senegalia bahiensis seeds. Semina: Ciências Agrárias, 38(3), 1103-1114. https://doi.org/10.5433/1679-0359.2017v38n3p1103

Lopes, R. R., \& Franke, L. B. (2011). Aspectos térmico-biológicos da germinação de sementes de cornichão anual sob diferentes temperaturas. Revista Brasileira de Zootecnia, 40(10), 2091-2096. https://doi.org/ $10.1590 / \mathrm{S} 1516-35982011001000004$

Lorenzi, H. (2016). Árvores brasileiras: Manual de identificação e cultivo de plantas arbóreas nativas do Brasil (5th ed.). Nova Odessa: Plantarum.

Machado, D. F. M., Bortolin, G. S., Paranhos, J. T., \& Silva, A. C. F. (2016). Temperatura, luz e desinfecção na germinação das sementes de Gochnatia polymorpha (Less.) Cabrera. Revista de Ciências Agrárias, 39(1), 144-152. https://doi.org/10.19084/RCA15046

Maguire, J. D. (1962). Seed of germination-aid in selection and evaluation for seedling emergence and vigor. Crop Science, 2(2), 176-177. https://doi.org/10.2135/cropsci1962.0011183X000200020033x

Marcos-Filho, J. (2015). Fisiologia de sementes de plantas cultivadas. Londrina: ABRATES.

Medeiros, R. L. S., Souza, V. C., Santos, J. N. B., Azeredo, G. A., \& Anjos, F. (2017). Seeds ecophysiology in an altitude marsh in Paraíba state, Brazil, aiming the conservation of the autochthonous biodiversity. Ciencia Florestal, 27(2), 697-705. https://doi.org/10.5902/1980509827754 
Melo, P. A. F. R., Cavalcante, M. I. P., Alves, E. U., Martins, C. C., \& Araújo, L. R. (2017). Substrates and temperatures in the germination of Eriotheca gracilipes seeds. Revista Ciência Agronômica, 48(2), 303-309. https://doi.org/10.5935/1806-6690.20170035

Missio, F. F., Silva, A. C., Higuchi, P., Longhi, S. J., Brand, M. A., Rios, P. D., ... Pscheidt, F. (2017). Atributos funcionais de espécies arbóreas em um fragmento de Floresta Ombrófila Mista em Lages - SC. Ciência Florestal, 27(1), 215-224. https://doi.org/10.5902/1980509826460

Nogueira, N. W., Torres, S. B., Freitas, R. M. O., Castro, T. H. S., \& Sá, F. V. S. (2017). 'Jurema-de-embira' seed germination under water stress and at different temperatures. Revista Brasileira de Engenharia Agrícola e Ambiental, 21(4), 244-248. https://doi.org/10.1590/1807-1929/agriambi.v21n4p244-248

Oliveira, F. N., França, F. D., Torres, S. B., Nogueira, N. W., \& Freitas, R. M. (2016). Temperaturas e substratos na germinação de sementes de pereiro-vermelho (Simira gardneriana M.R. Barbosa \& Peixoto). Revista Ciência Agronômica, 47(4), 658-666. https://doi.org/10.5935/1806-6690.20160079

Oliveira, F. N., Oliveira, J. R., Torres, S. B., Freitas, R. M. O., \& Nogueira, N. W. (2017). Germination and initial development of Simira gardneriana seedling under water stress and at different temperatures. Revista Brasileira de Engenharia Agrícola e Ambiental, 21(5), 333-338. https:/doi.org/10.1590/1807-1929/ agriambi.v21n5p333-338

Primack, R. B. (1980). Variation in the phenology of natural populations of montane shrubs in New Zealand. Journal of Ecology, 68(3), 849-862. https://doi.org/10.2307/2259460

Ranal, M. A., \& Santana, D. G. (2006). How and why to measure the germination process? Revista Brasileira de Botânica, 29(1), 1-11. https://doi.org/10.1590/S0100-84042006000100002

Rios, P. A. F., Araújo Neto, J. C., Ferreira, V. M., \& Neves, M. I. R. S. (2016). Seed morphometry and germination of Aechmea costantinii (Mez) L. B. Sm. (Bromeliaceae). Revista Caatinga, 29(1), 85-93. https://doi.org/10.1590/1983-21252016v29n110rc

Sanhueza, C., Vallejos, V., Cavieres, L. A., Saez, P., Bravo, L. A., \& Corcuera, L. J. (2017). Growing temperature affects seed germination of the antarctic plant Colobanthus quitensis (Kunth) Bartl (Caryophyllaceae). Polar Biology, 40(2), 449-455. https://doi.org/10.1007/s00300-016-1972-4

Silva, M. L. M., Alves, E. U., Bruno, R. L. A., Santos-Moura, S. S., \& Santos Neto, A. P. (2016). Germinação de sementes de Chorisia glaziovii O. Kuntze submetidas ao estresse hídrico em diferentes temperaturas. Ciência Florestal, 26(3), 999-1007. https://doi.org/10.5902/1980509824229

Silva, R. B., Matos, V. P., Farias, S. G. G., Sena, L. H. M., \& Silva, D. Y. B. O. (2017). Germinação e vigor de plântulas de Parkia platycephala Benth. em diferentes substratos e temperaturas. Revista Ciência Agronômica, 48(1), 142-150. https://doi.org/10.5935/1806-6690.20170016

Taiz, L., Zeiger, E., Møller, I. M., \& Murphy, A. (2017). Fisiologia e desenvolvimento vegetal (6th ed.). Porto Alegre: Artmed.

Zpevak, F. A., Perez, S. C. J. G. A., \& Buckeridge, M. S. (2012). Isothermal seed germination of Adenanthera pavonina. Brazilian Journal of Botany, 35(4), 401-408. https://doi.org/10.1590/S0100-84042012000400013

\section{Copyrights}

Copyright for this article is retained by the author(s), with first publication rights granted to the journal.

This is an open-access article distributed under the terms and conditions of the Creative Commons Attribution license (http://creativecommons.org/licenses/by/4.0/). 